\title{
Impact of chromophoric dissolved organic matter on UV inhibition of primary productivity in the sea
}

\author{
Kevin R. Arrigo*, Christopher W. Brown** \\ Oceans and Ice Branch, Code 971, NASA Goddard Space Flight Center, Greenbelt, Maryland 20771, USA
}

\begin{abstract}
A model was developed to assess the impact of chromophoric dissolved organic matter (CDOM) on phytoplankton production within the euphotic zone. The rate of depth-integrated daily gross primary productivity within the euphotic zone $\left(\int_{z} \mathrm{GPP}_{\mathrm{e} z}\right)$ was evaluated as a function of date, latitude, CDOM absorption (a $\left.a_{C D O M}\right)$ characteristics, chlorophyll a (chl a) concentration, vertical stratification, and phytoplankton sensitivity to UV radiation (UVR). Results demonstrated that primary production was enhanced in the upper $-30 \mathrm{~m}$ of the water column by the presence of CDOM, where predicted increases in production due to the removal of damaging UVR more than offset its reduction resulting from the absorption of photosynthetically usable radiation. At greater depths, where little UVR remained, primary production was always reduced due to removal by CDOM of photosynthetically usable radiation. When CDOM was distributed homogeneously within the euphotic zone, $\int_{2} \mathrm{GPP}_{\mathrm{e}}$ was reduced under most bio-optical (i.e. solar zenith angle, chl a and CDOM absorption, and ozone concentration) and photophysiological (1.e. sensitivity to UVR) conditions because the predicted reduction in primary production at depth was greater than the enhancement of production at the surface. A reduction in $\int_{Y} \mathrm{GPP}$, was also predicted when CDOM or phytoplankton was restricted to near-surface waters $(-30 \mathrm{~m})$ and CDOM absorption was moderate $\left[a_{C D O M}(450)>0.015 \mathrm{~m}^{-1}\right.$ ]. $\int_{2} \mathrm{GPP}_{\mathrm{e} z}$, however, was enhanced when CDOM or phytoplankton was restricted to a very shallow surface layer ( $10 \mathrm{~m})$, even if CDOM absorption was high $\left[a_{C D O M}(\lambda)\right.$ at $450 \mathrm{~nm} \sim 0.07 \mathrm{~m}^{-1}$. Changes in $\int, \mathrm{GPP}_{\mathrm{e}}$ resulting from the presence of CDOM were only slightly sensitive to ozone concentratıons. In well-mixed waters where the flux of UVB is relatively high, such as in the Southern Ocean when the ozone hole is present, the presence of CDOM should result in little or no enhancement of $\int_{z} G P P_{e z}$, although phytoplankton production would be expected to increase somewhat in surface waters.
\end{abstract}

KEY WORDS: CDOM UV Photosynthesis - Primary production

\section{INTRODUCTION}

Recent studies have demonstrated that ambient levels of ultraviolet radiation (UVR, 280 to $400 \mathrm{~nm}$ ) can substantially decrease rates of carbon fixation by phytoplankton (Karentz et al. 1991, Cullen et al. 1992, Helbling et al. 1992, Smith et al. 1992, Holm-Hansen et al. 1993a). At normal ozone $\left(\mathrm{O}_{3}\right)$ concentrations, i.e 344 Dobson Units (DU), UVR has been found to reduce primary productivity in surface waters by as much as 50\% (Cullen et al. 1992, Holm-Hansen et al. 1993b, Cullen \& Neale 1994). Because seawater strongly

\footnotetext{
-E-mail: kevin@shark.gsfc.nasa.gov

- Present address: Satellite Research Laboratory, NOAA/ NESDIS, E/RA13, Washington, DC 20233, USA
}

attenuates UVR, particularly at shorter wavelengths, UVR inhibition is most severe near the sea surface. For example, along $50^{\circ} \mathrm{S}$ in mid December, a normal level of UVR was estimated to reduce phytoplankton production by $57 \%$ at a depth of $1 \mathrm{~m}$, while UVR inhibition decreased to $<5 \%$ at $30 \mathrm{~m}$ (Arrigo 1994). Inhibition associated with UVR is due primarily to UVA (320 to $400 \mathrm{~nm}$ ), which is more abundant at the sea surface and is attenuated less strongly in the water column than the more damaging UVB (280 to $320 \mathrm{~nm}$ ). Estimates of UVR inhibition resulting from $\mathrm{O}_{3}$ depletion range from an additional 1 to $12 \%$ of depth-integrated daily primary productivity (Smith et al. 1992, HolmHansen et al. 1993a, Arrigo 1994), due to the increased atmospheric transmission of UVB (UVA is not affected by changes in $\mathrm{O}_{3}$ ) 
The degree to which the increased flux of incoming UVR affects phytoplankton photosynthesis depends in part upon the optical characteristics of the water column. In addition to pure seawater, which attenuates radiation between 280 and $400 \mathrm{~nm}$, particulates such as phytoplankton, bacteria, and detritus also absorb UVR. Holm-Hansen et al. (1993b) measured total particulate absorption coefficients at $300 \mathrm{~nm}$ as ranging from 0.1 to $0.3 \mathrm{~m}^{-1}$ in Southern Ocean waters. Specific absorption coefficients for Antarctic phytoplankton have been reported to exceed $0.1 \mathrm{~m}^{2}$ ( $\mathrm{mg} \mathrm{chl} \mathrm{a)^{-1 }}$ within the UV range (Mitchell et al. 1989, Arrigo 1994). Kopelevich et al. (1987) showed that bacterial attenuation at $390 \mathrm{~nm}$ ranged from $0.002 \mathrm{~m}^{-1}$ for Micrococcus $\mathrm{sp}$. to $2.80 \mathrm{~m}^{-1}$ for Moraxella sp. at concentrations of 1012 cells $\mathrm{m}^{-3}$, and increased markedly at shorter wavelengths.

Many dissolved constituents within seawater, such as chromophoric dissolved organic matter (CDOM): are also strong absorbers of UVR, often having absorption coefficients that are higher than those of both seawater and suspended particulates. CDOM absorption within the UV is greatest at $280 \mathrm{~nm}$ and declines exponentially at greater wavelengths (Fig. 1). The slope of $\log$ (absorption) versus wavelength is typically in the range of 0.012 to $0.029 \mathrm{~nm}^{-1}$ (Bricaud et al. 1981, Carder et al. 1989, Blough et al. 1993, Hoge et al. 1993, Green \& Blough 1994)

CDOM absorption can be highly variable both temporally and spatially, changing as a function of CDOM concentration and specific absorption (Carder et al. 1989, Blough et al. 1993). Carbon-specific absorption coefficients for riverine sources of CDOM are 10 to 150 times greater than those of marine CDOM (Carder et al. 1989), either because these forms of CDOM are more strongly absorbing or because a greater proportion of riverine DOC consists of CDOM. Consequently, coastal waters typically possess higher CDOM absorp-

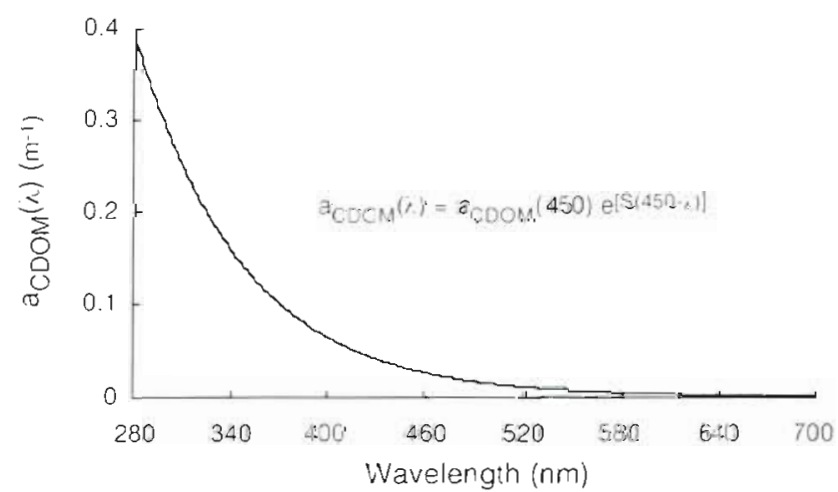

Fig. 1. Equation used to describe the carbon-specific absorption spectrum for chromophoric dissolved organic matter (acuom) and its corresponding shape. The coefficient $a_{6 \text { com }}(450)=$ $0.03 \mathrm{~m}^{-1}$ and the spectral slope $S=0.015 \mathrm{~nm}^{-1}$ tion coefficients than open ocean waters. For example, CDOM absorption in the near-shore waters of the Delaware Bay, USA, ranged from $<0.05$ to $0.38 \mathrm{~m}^{-1}$ at $442 \mathrm{~nm}$ (M. D. DeGrandpre unpubl.) while those measured at offshore sites in the Gulf of Mexico were approximately an order of magnitude lower, varying from 0.002 to $0.068 \mathrm{~m}^{-1}$ at $440 \mathrm{~nm}$ (Carder et al. 1989 Green \& Blough 1994).

As an absorber of radiation within the water column, CDOM plays 2 distinct roles in the marine environment. First, because CDOM strongly absorbs UVR, it may act as a UV photoprotectant and reduce the deleterious effect of UVR on phytoplankton, particularly in regions of ozone depletion, such as the Southern Ocean, where fluxes of UVR are increasing. Second, CDOM also attenuates photosynthetically usable radiation (PUR, that portion of photosynthetically available radiation, $P A R$, between $400 \mathrm{~nm}$ and $700 \mathrm{~nm}$ that can potentially be absorbed by phytoplankton pigments), which will reduce primary productivity in regions where light is limiting. The primary objective of this study was to assess the relative importance of these 2 opposing influences of CDOM and evaluate how these processes vary under a wide variety of environmental conditions. Specifically, we investigated how the impact of CDOM on depth-integrated rates of primary production changes as a function of the vertical distributions and concentrations of chl a and CDOM, CDOM absorption properties, latitude, and stratospheric ozone concentration. We have restricted our study to the open ocean where CDOM absorption is less variable and therefore more easily characterized, though our general conclusions are likely to be applicable in coastal waters.

\section{METHODS}

The 1-dimensional model of Arrigo (1994) was used to compute the depth-dependent variation in primary production as a function of the spectral distribution of incoming solar radiation (280 to $700 \mathrm{~nm}$ ). Included in the model were separate components for calculating the flux of atmospheric radiation, in-water bio-optics, and primary production. The model calculated the rate of gross primary production (mg $\mathrm{C} \mathrm{m}^{-3} \mathrm{~d}^{-1}$ ) at $1 \mathrm{~m}$. vertical resolution on an hourly basis as a function of diurnal changes in spectral irradiance. UV inhibition of primary production was calculated using the biological weighting function ( $\varepsilon$ ) provided by Cullen et al. (1992). Production was integrated over depth (the euphotic depth, $0.1 \%$ of surface PAR) and time (24 h) to determine daily production on an areal basis $\left(\int_{Z} \mathrm{GPP}_{\mathrm{cz}}, \mathrm{mg} \mathrm{C}\right.$ $\left.\mathrm{m}^{-2} \mathrm{~d}^{-1}\right)$. Note that $\int_{z} G P P_{\mathrm{ez}}$ is defined here as the depth integrated rate of primary productivity, not the produc- 
tivity at a given depth. Model input included day of the year, latitude, seawater temperature $\left({ }^{\circ} \mathrm{C}\right)$, stratospheric $\left[\mathrm{O}_{3}\right](\mathrm{DU})$, vertical distributions of phytoplankton (mg $\mathrm{C} \mathrm{m}^{-3}$ ) and CDOM (g CDOM-C m${ }^{-3}$ ) concentrations, and biomass-specific absorption coefficients. The effects of changes in UVR and PUR were determined independently by setting a flag that controls whether UV inhibition was calculated or not. If inhibition was not calculated, changes in production resulting from diminished $\mathrm{O}_{3}$ were due to variation in PUR only.

Details of the model used in the present analysis can be found in Arrigo (1994); for convenience, the basic formulations are listed in Table 1. Diffuse attenuation by CDOM, not modeled by Arrigo (1994), has been described by the equation

$$
K_{\mathrm{CDOM}}(\lambda)=\frac{a_{\mathrm{CDOM}}(\lambda)}{\mu}
$$

where $K_{\mathrm{CDOM}}(\lambda)$ and $a_{\mathrm{CDOM}}(\lambda)$ are the diffuse attenuation and absorption coefficients $\left(\mathrm{m}^{-1}\right)$, respectively, for CDOM, and $\mu$ (dimensionless) is the mean cosine of the angular distribution of the downwelling light field. It has been shown that $a_{\mathrm{CDOM}}(\lambda)$ takes the form

$$
a_{\mathrm{CDOM}}(\lambda)=a_{\mathrm{CDOM}}\left(\lambda_{\mathrm{r}}\right) \exp \left[S\left(\lambda-\lambda_{\mathrm{s}}\right)\right]
$$

where $a_{C D O M}\left(\lambda_{r}\right)$ is the absorption by CDOM at the reference wavelength, $\lambda_{r}$, and $S\left(\mathrm{~nm}^{-1}\right)$ is the slope of $\log$ (absorption) versus wavelength.

A total of 512 simulations were performed. The conditions for the standard simulations were temperature $=0^{\circ} \mathrm{C}, \lambda_{\mathrm{r}}=450 \mathrm{~nm}, a_{\mathrm{CDOM}}(450)=0.03 \mathrm{~m}^{-1}, S=0.015$ $\mathrm{nm}^{-1}$, and chl a $=0.1 \mathrm{mg} \mathrm{m}^{-3}$. Ozone concentrations tested were 172 and 344 DU, latitude ranged from $45^{\circ} \mathrm{S}$ to $75^{\circ} \mathrm{S}$, and day of the year varied from 220 to 360 . UV inhibition of primary production was routinely included in the standard simulation. All quantities were assumed to be constant with depth unless otherwise specified. The values for $a_{\mathrm{CDOM}}(450)$ and $S$ used in Eq. (2) were derived by averaging similar measurements presented in Bricaud et al. (1981) and Green \& Blough (1994) for the open ocean. In most cases, sensitivity analyses were compared to results of the standard simulation and the differences between 2 corresponding runs are presented.

Table 1. Equations used in the model. Details can be found in Arrigo (1994) and Arrigo \& Sullivan (1994)

$$
\begin{aligned}
& \text { Spectral light distribution } \\
& \left(\mu \text { Ein } \mathrm{m}^{-2} \mathrm{~s}^{-1}\right) \text { : } \\
& \text { Bulk diffuse attenuation } \\
& \text { coefficient }\left(\mathrm{m}^{-1}\right) \text { : } \\
& \text { Diffuse attenuation for } \\
& \text { particulates }\left(\mathrm{m}^{-1}\right) \text { : } \\
& \text { Mean cosine for } \\
& \text { downwelling radiation: } \\
& \text { Gross microalgal production } \\
& \left(\mathrm{mg} \mathrm{C} \mathrm{m}{ }^{-3} \mathrm{~h}^{-1}\right) \text { : } \\
& \text { Rate of phytoplankton } \\
& \text { growth }\left(\mathrm{d}^{-1}\right) \text { : } \\
& \text { Maximum phytoplankton } \\
& \text { growth rate }\left(\mathrm{d}^{-1}\right) \text { : } \\
& \text { Light limitation } \\
& \text { (dimensionless): } \\
& \text { Photoadaptation parameter } \\
& \left(\mu \text { Ein } \mathrm{m}^{-2} \mathrm{~s}^{-1}\right) \text { : }
\end{aligned}
$$

$\lambda(\mathrm{nm})$ is wavelength

$z(\mathrm{~m})$ is depth

$t(h)$ is time

$K_{\mathrm{w}}\left(\mathrm{m}^{-1}\right)$ is the extinction coefficient for clear ocean water

$b_{c}\left(\mathrm{~m}^{-1}\right)$ is the backscatter by microalgae

$a^{*},\left(m^{2} \mathrm{mg} \mathrm{chl} a^{-1}\right)$ is the pigmentspecific absorption coefficient for phytoplankton

$C\left(\mathrm{mg} \mathrm{chl} a \mathrm{~m}^{-3}\right)$ is the pigment concentration

$P$ (mg C $\mathrm{m}^{-3}$ ) is the phytoplankton standing crop

$G_{\circ}\left(d^{-1}\right)$ is the microalgal growth rate at $0^{\circ} \mathrm{C}$

$T\left({ }^{\circ} \mathrm{C}\right)$ is temperature

$r\left({ }^{\circ} \mathrm{C}^{-1}\right)$ is a rate constant that determines the sensitivity of $G_{\max }$ to $T$

$I_{k}^{\prime}{ }^{\prime}$ max is the maximum observed value for $I_{k}^{\prime}$

$F(h)$ is the photoperiod

$D_{E}(m)$ is the euphotic depth

$a_{\text {crmax }}\left(\mathrm{m}^{2} \mathrm{mg} \mathrm{chl} \mathrm{a}^{-1}\right)$ is the maximum value attained by $a_{c}^{\cdot}(\lambda)$

$\varepsilon(\lambda)\left[\left(\mathrm{mW} \mathrm{m}^{-2}\right)^{-1}\right]$ is the wavelengthdependent efficiency for damage to photosynthesis by UV 


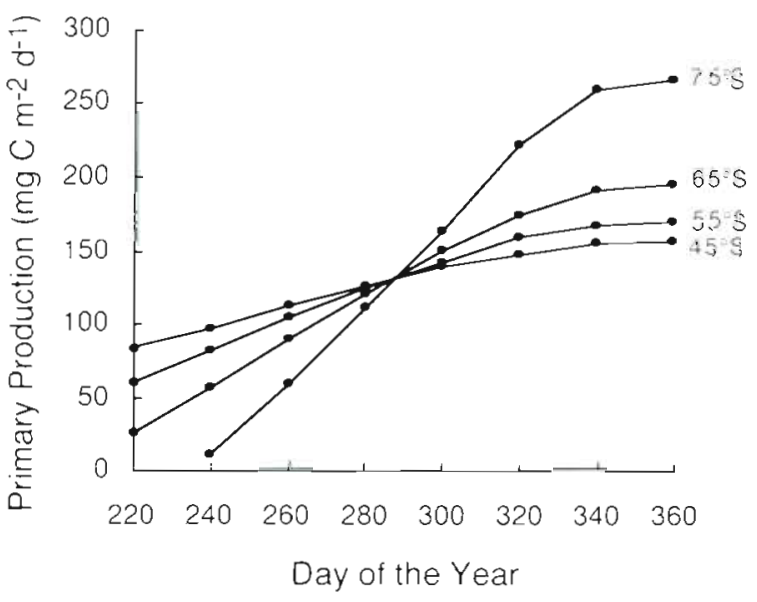

Fig. 2. Seasonal changes in gross primary productivity (mg C $\mathrm{m}^{-2} \mathrm{~d}^{-1}$ ) as a function of latitude for the standard simulations. Each data point represents a separate simulation

\section{RESULTS}

In the standard run, primary productivity varied as a function of the day of the year and latitude, ranging from 0 to $286 \mathrm{mg} \mathrm{C} \mathrm{m}^{-2} \mathrm{~d}^{-1}$ (Fig. 2). Productivity was lowest in late austral winter at $75^{\circ} \mathrm{S}$ when the photoperiod was $<1$ h and the sun remained low in the sky. Rates of production increased with time at all latitudes, the increase being most pronounced at high latitudes where changes in photoperiod were most rapid. Predicted rates of production were highest during the summer solstice at $75^{\circ} \mathrm{S}$, the time and location of maximum photoperiod $(24 \mathrm{~h})$. Although the solar elevation was greater at lower latitudes, this did not compensate for the longer photoperiod at higher latitudes.
To assess the amount of UV inhibition of $\int_{z} G_{P P}$ under a given suite of conditions (i.e. ozone concentration, day of the year, and latitude), we calculated the difference between 2 corresponding simulations, one where UV inhibition was calculated (standard simulation) and the other where it was neglected. The spatial and temporal variation in UV inhibition of $\int_{z} \mathrm{GPP}_{\mathrm{ez}}$ was determined for $a_{C D O M}(450)=0$ and $a_{C D O M}(450)=$ $0.03 \mathrm{~m}^{-1}$ as ozone concentration varied from 172 to 344 DU (Fig. 3A, C). Results show that in the absence of CDOM, UV inhibition reduced $\int_{z} \mathrm{GPP}_{\mathrm{ez}}$ by as much as $9.2 \%$ Inhibition was greatest at low latitudes in early austral summer (Fig. 3A). This was due to the increased flux of UVR resulting from the shorter pathlength through the atmosphere at these increased solar elevations. When CDOM was present at all depths, model results followed the same pattern but UV inhibition of $\int_{2} \mathrm{GPP}_{\mathrm{e} 7}$ was reduced by $\sim 50 \%$ (Fig $3 \mathrm{~B}$ ). The magnitude of this reduction is a measure of the mitigation of UV inhibition provided by the presence of CDOM, i.e. its UV photoprotective capacity (Fig. 4A). The level of UV inhibition of $\int_{Z} G_{P P} P_{e z}$ and of photoprotection by CDOM, changed only slightly when ozone concentration was reduced by $50 \%$ (Fig. 3C, D).

CDOM absorption of PUR was computed to reduce $\int_{Z} \mathrm{GPP}_{\mathrm{ez}}$ by as much as $24 \%$ at low solar elevations $\left(75^{\circ} \mathrm{S}\right.$ and day of year 260$)$ when light was most limiting to phytoplankton growth (Fig. 4B). Reduction of $\int_{z} G_{P P}$ was less severe later in the year at higher sun elevations. This trend was not particularly sensitive to ozone concentrations ranging between 172 and 344 DU (Fig 4B, E).

When the combined effect of CDOM absorption of PUR and UVR are integrated over the depth of the euphotic zone, it becomes apparent that the presence
Fig. 3. (A) Seasonal changes in the magnitude of UV inhibition of gross primary productivity as a function of latitude for $a_{C D O M}[450)=0$ and $\left[\mathrm{O}_{3}\right]=344$ Dobson Units (DU). (B) Same as (A) but $a_{\text {CDOM }}(450)=0.03 \mathrm{~m}^{-1}$ (C) Same as $(A)$ but $\left[\mathrm{O}_{3}\right]=172 \mathrm{DU}$. (D) Same as $(\mathrm{A})$ but $[\mathrm{CDOM}]=0.03 \mathrm{~m}^{-1}$ and $\left[\mathrm{O}_{3}\right]=172 \mathrm{DU}$

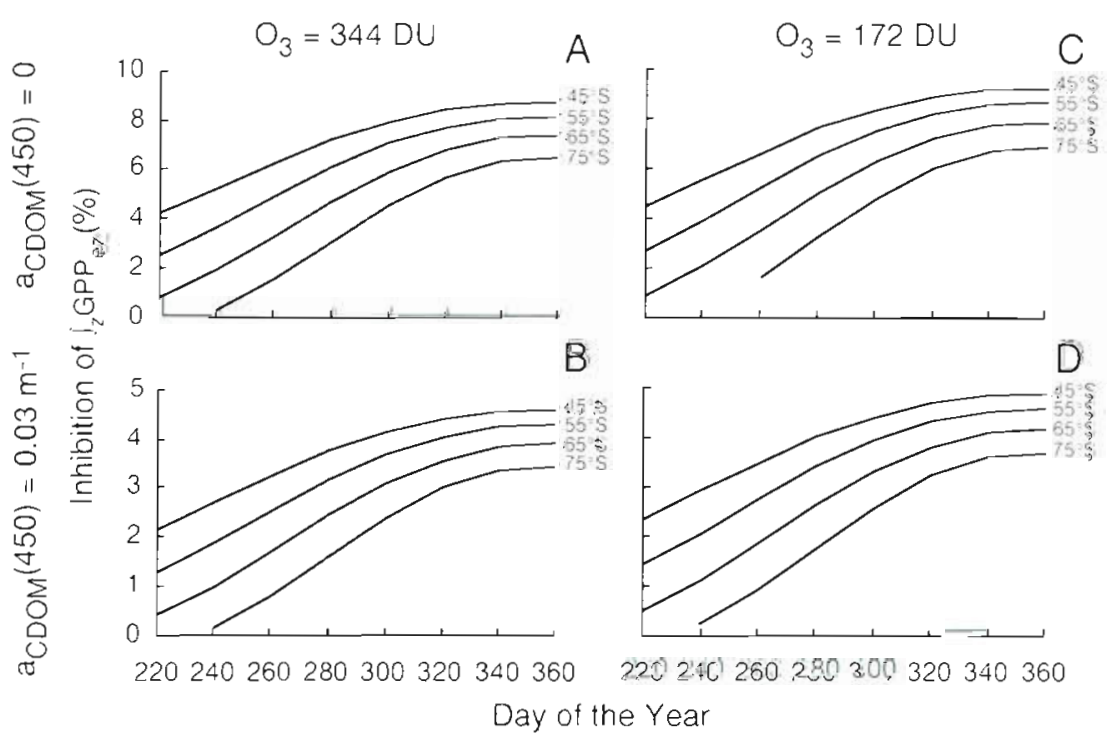


Fig. 4. (A) Enhancement of the rate of depth-integrated daily gross primary production within the euphotic zone $\left(\int_{z} G P P_{e z}\right)$ due to absorption of damaging ultraviolet radiation (UVR) by $\mathrm{CDOM}$ for $\left[\mathrm{O}_{3}\right]=344$ DU, caiculated as the difference between corresponding simulations shown in Fig. 3A, B. (B) lnhibition of $\int_{z} \mathrm{GPP}_{\mathrm{ez}}$ due to absorption of photosynthetically usable radiation (PUR) by CDOM for $\left[\mathrm{O}_{3}\right] 344 \mathrm{DU}$. (C) Net inhibition of $\int_{7} \mathrm{GPP}_{\mathrm{e} z}$ due to the presence of $\mathrm{CDOM}$ at $\left[\mathrm{O}_{3}\right]=344 \mathrm{DU}$. includes both the enhancement and inhibition of $\int_{z} \mathrm{GPP}_{\mathrm{ez}}$ due to UV and PUR absorption, respectively, by CDOM. (D) Same as (A) but $\left[\mathrm{O}_{3}\right]=172$ DU. (E) Same as $(B)$ but $\left[\mathrm{O}_{3}\right]=172 \mathrm{DU}$.

(F) Same as (C) but $\left[\mathrm{O}_{3}\right]=172 \mathrm{DU}$
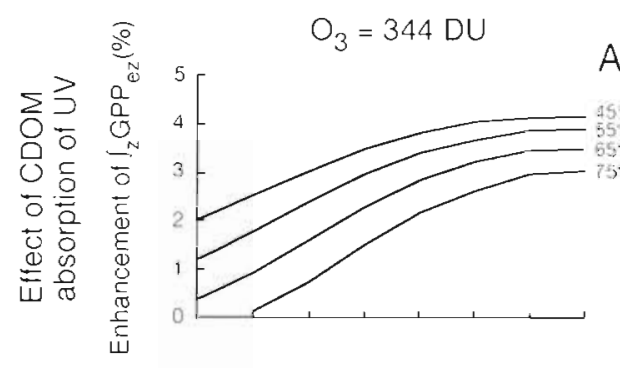

$\mathrm{O}_{3}=344 \mathrm{DU}$
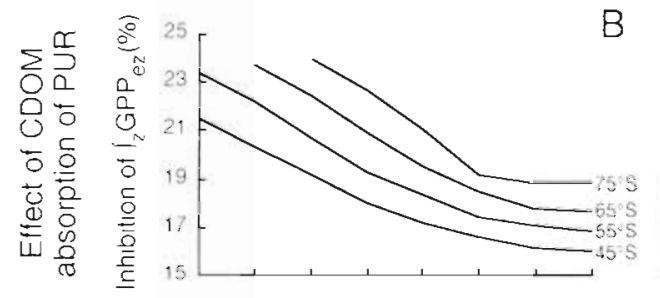

B

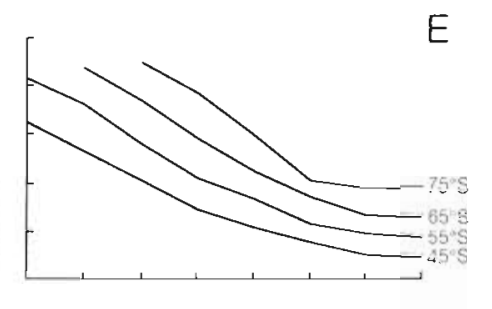

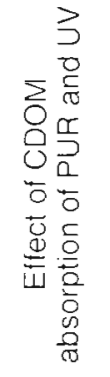

C

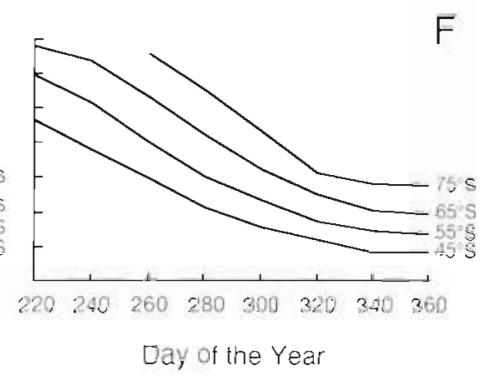

of CDOM results in a net decrease of $\int_{z} G_{P P}$ (Fig. $4 \mathrm{C}$ ). This is because the reduction in $\int_{z} G P P_{\mathrm{e} z}$ due to the absorption of PUR by CDOM (Fig. 4B) was not fully compensated for by the slight photoprotection provided by its absorption of damaging UVR (Fig. 4A). The net decrease in $\int_{z} G_{P P}$ was $\sim 19$ to $24 \%$ during periods of low light levels in the presence CDOM (Fig. 4C), diminishing to 12 to $16 \%$ later in the year. Results were similar when ozone concentration was reduced to $172 \mathrm{DU}$ (Fig. $4 \mathrm{D}, \mathrm{E}, \&$ F).

Vertical profiles of downwelling irradiance and noontime production for 2 simulations representing the extremes in the irradiance field (August $28,75^{\circ} \mathrm{S}$ and $45^{\circ} \mathrm{S}$, December 26) were examined to ascertain the range of variability produced by the presence of CDOM. Both irradiance (Fig. 5A) and production (Fig. 5C) decreased exponentially with depth at the

Fig. 5. Simulated vertical profiles of noontime downwelling irradiance and production for August 28 at $75^{\circ} \mathrm{S}$ and for December 26 at $45^{\circ} \mathrm{S}$ in waters with (w/) and without (w/o) CDOM. These simulations were chosen because they represent the extremes in the range of solar zenith angles for our region of interest. The hatched areas labeled $\mathrm{PP}^{+}$and $\mathrm{PP}^{-}$represent the depth-integrated differences where production is enhanced and reduced, respectively

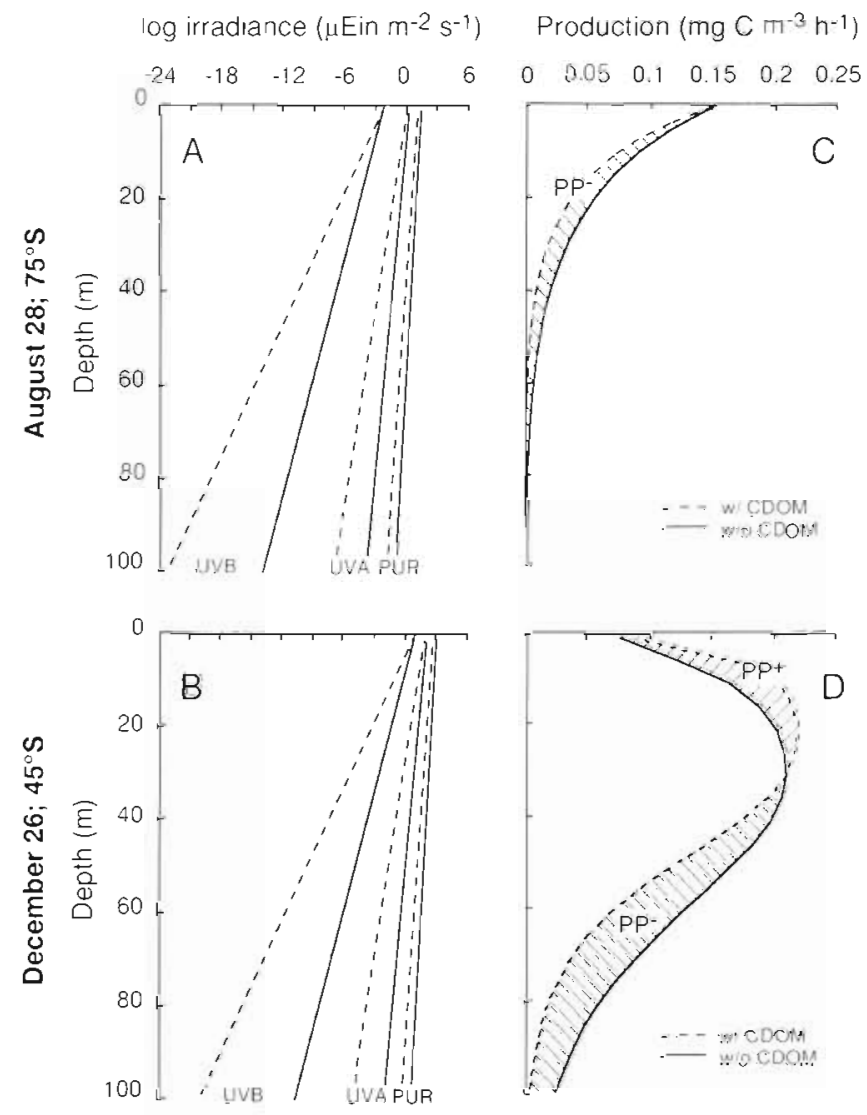


low light regime of $75^{\circ} \mathrm{S}$ on August 28. UVA, UVB, PUR, and production were reduced in waters containing CDOM. This pattern was also evident at the high light environment of $45^{\circ} \mathrm{S}$ on December 26, although the absolute irradiances of all 3 wavelength bands were greater (Fig. 5B). Production, in this case, revealed a subsurface maximum (Fig. 5D) due to UV inhibition in surface waters. In the presence of CDOM, the depth of the production peak was shifted upward slightly $(\sim 10 \mathrm{~m})$ relative to waters without CDOM. resulting in increased rates of production near the surface and reduced rates at greater depths (Fig. 5D).

Calculating the total radiation absorbed by CDOM above a given depth illustrates that depth-dependent differences in production were due to changes in the vertical light field resulting from CDOM absorption (Fig. 6). Absorbed radiation was determined by integrating the difference in irradiance spectra calculated at a given depth with and without CDOM over UVR and PUR wavelengths. On December 26 (day of the year 360 ) at $45^{\circ} \mathrm{S}$, at a depth of $10 \mathrm{~m}$, this difference was $38.7 \mu$ Ein $\mathrm{m}^{-2} \mathrm{~s}^{-1}$ for UVR and $121.6 \mu$ Ein $\mathrm{m}^{-2} \mathrm{~s}^{-1}$ for PUR (Fig. 6A). The ratio of UVR:PUR absorbed by CDOM was 0.307 . At $75 \mathrm{~m}$, this difference was reduced to $0.03 \mu$ Ein $\mathrm{m}^{-2} \mathrm{~s}^{-1}$ for UVR and $34.0 \mu \mathrm{Ein} \mathrm{m}^{-2} \mathrm{~s}^{-1}$ for PUR (Fig, 6C), decreasing the ratio of UVR:PUR absorbed to 0.008 . Therefore, the relative absorption of UVR versus PUR was $>35$ times greater at a depth of $10 \mathrm{~m}$ than at $75 \mathrm{~m}$. This same general trend was also observed for the low light simulation of August 28 at $75^{\circ} \mathrm{S}$ (Fig, 6B, D). Consequently, at shallower depths, where CDOM absorbs proportionally more UVR than
PUR, productivity will be enhanced by the presence of CDOM. At greater depths where UVR is scarce, the presence of CDOM will have little photoprotective effect.

The depth-dependent pattern of primary production (PP) predicted in the presence and absence of CDOM (Fig. 5D) is useful for understanding how CDOM alters rates of productivity throughout the water column. The region of Fig. 5D labeled $\mathrm{PP}^{+}$represents those depths where the presence of CDOM enhances productivity. In this region of the water column, the UV photoprotection provided by CDOM is greater than the reduction in productivity due to the removal of PUR by CDOM. In contrast, $\mathrm{PP}^{-}$represents those depths where the presence of CDOM results in a net reduction in productivity. The size of the area of regions $\mathrm{PP}^{+}$and $\mathrm{PP}^{-}$is a direct measure of the change in noontime depth-integrated production ( $\mathrm{mg} \mathrm{C} \mathrm{m}^{-2} \mathrm{~h}^{-1}$ ) due to the presence of CDOM. The percent change in primary production due to the presence of CDOM can be described by the quantity $\mathrm{PP}^{*}(\%)$, which is calculated as

$$
\mathrm{PP}^{*}=\frac{\left(\mathrm{PP}^{+}\right)-\left(\mathrm{PP}^{-}\right)}{\mathrm{PP}} \cdot 100
$$

where PP is the rate of primary production when no CDOM is present. Values for PP ${ }^{*}$ greater than 0 indicate a net increase in depth integrated production $\left(\int_{z} G_{P P}\right)$ due to the presence of CDOM. Changes in PP. will be used below to evaluate the relative importance of various biotic and abiotic factors influencing $\int_{z} G P P_{\mathrm{ez}}$.

Increasing $a_{\text {CDOM }}(450)$ always resulted in a lower $\mathrm{PP}^{*}$ (Table 2). For example, an increase from $0.03 \mathrm{~m}^{-1}$ (as in the standard run) to $0.07 \mathrm{~m}^{-1}$ resulted in a $39 \%$
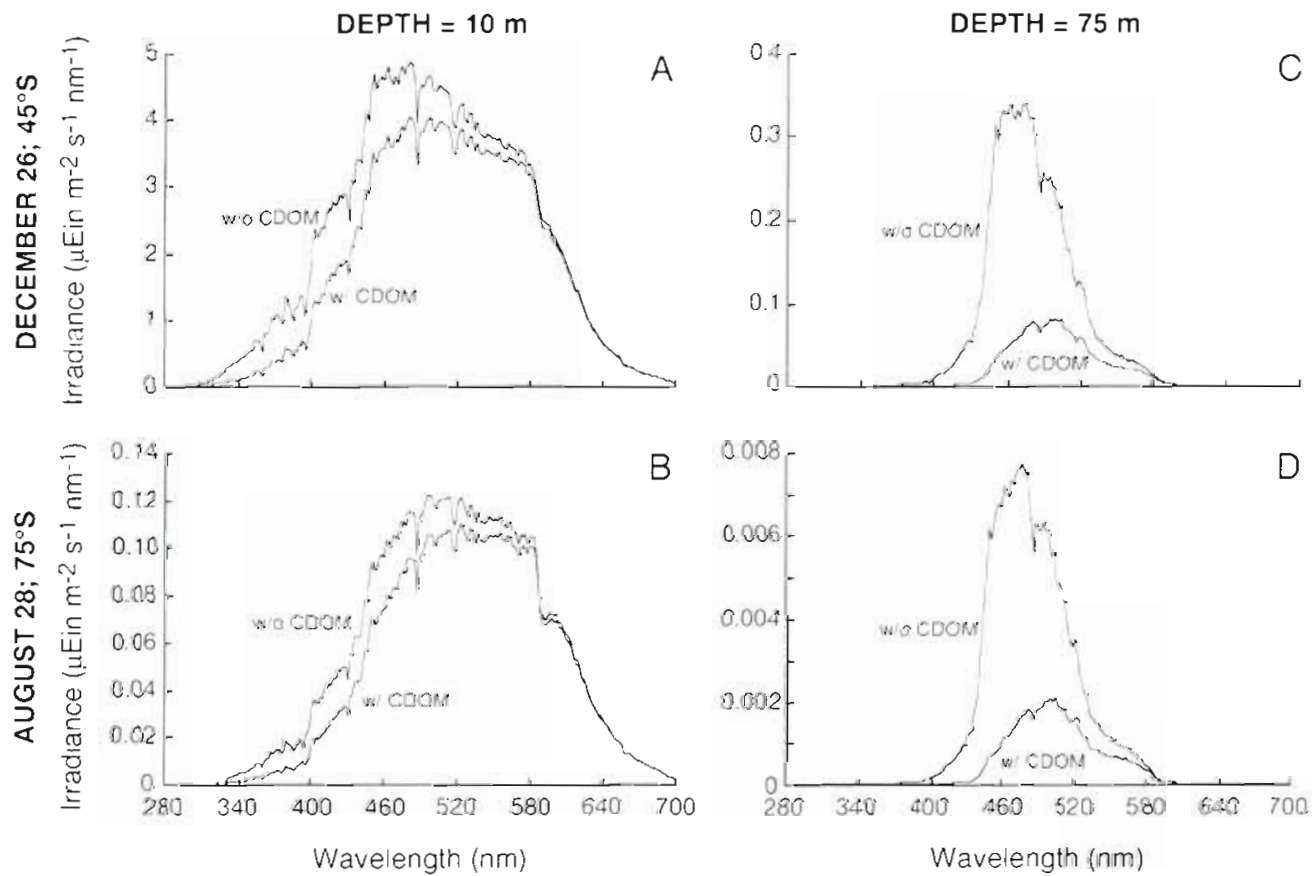

Fig. 6. Subsurface spectral irradiance in waters with (w/) CDOM $\left|a_{\operatorname{cocm}}(450)=0.03 \mathrm{~m}^{-1}\right|$ and in waters without (w/o) CDOM at depths of (A) $10 \mathrm{~m}$ on December 26, (B) $10 \mathrm{~m}$ on August 28, (C) $75 \mathrm{~m}$ on December 26, (D) and $75 \mathrm{~m}$ on August 28 
Table 2 . Sensitivity of model to $z_{C D O M}$ (the depth over which CDOM is distributed) and $a_{\text {Coom }}(450) . \mathrm{PP}^{+}\left(\mathrm{mg} \mathrm{C} \mathrm{m}^{-2} \mathrm{~h}^{-1}\right)$ denotes the noontime depth-integrated net increase in production at those depths where the

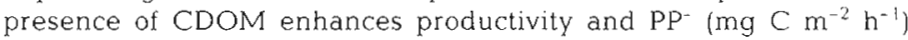
denotes the noontime depth-integrated net decrease in production at those depths where the presence of CDOM reduces productivity (see Fig. 5). $\mathrm{PP}$ " is the percent change in primary production due to the presence of CDOM [(PP+ $\left.-\mathrm{PP}^{-}\right) / \mathrm{PP}$, see 'Results']. $Z_{(\mathrm{COM})}$ is the depth over which CDOM is distributed within the water column. Unless otherwise noted, variable values for all simulations were: day of year $=350$, latitude $=45^{\circ} \mathrm{S},\left[\mathrm{O}_{3}\right]=344 \mathrm{DU},[\mathrm{chl} \mathrm{a}]=0.1 \mathrm{mg} \mathrm{m}^{-3}, \mathrm{~S}=0.015$ $\mathrm{nm}^{-1}$, and $\mathrm{C}: \mathrm{chl} a=50(\mathrm{~g}: \mathrm{g})$

\begin{tabular}{|c|c|c|c|}
\hline Parameter & $\mathrm{PP}^{+}$ & $\mathrm{PP}^{-}$ & $\mathrm{PP}^{\cdot}$ \\
\hline $\begin{array}{l}a_{C D O M}(450)=0.01 \mathrm{~m}^{-1}, z_{C D O M}=100 \mathrm{~m} \\
a_{\text {CDOM }}(450)=0.03 \mathrm{~m}^{-1}, z_{\mathrm{CDOM}}=100 \mathrm{~m} \\
a_{\text {CDOM }}(450)=0.05 \mathrm{~m}^{-1}, z_{\mathrm{CDOM}}=100 \mathrm{~m} \\
a_{\text {CDOM }}(450)=0.07 \mathrm{~m}^{-1}, z_{\mathrm{CDOM}}=100 \mathrm{~m}\end{array}$ & $\begin{array}{l}0.35 \\
0.70 \\
0.89 \\
0.97\end{array}$ & $\begin{array}{l}0.93 \\
2.60 \\
3.92 \\
4.92\end{array}$ & $\begin{array}{r}-4.5 \\
-14.8 \\
-23.6 \\
-30.6\end{array}$ \\
\hline $\begin{array}{l}a_{\text {CDOM }}(450)=0.01 \mathrm{~m}^{-1}, z_{\text {CDOM }}=30 \mathrm{~m} \\
a_{\text {CDOM }}(450)=0.03 \mathrm{~m}^{-1}, z_{\text {CDOM }}=30 \mathrm{~m} \\
a_{\text {CDOM }}(450)=0.05 \mathrm{~m}^{-1}, z_{\mathrm{CDOM}}=30 \mathrm{~m} \\
a_{\text {CDOM }}(450)=0.07 \mathrm{~m}^{-1}, z_{\text {CDOM }}=30 \mathrm{~m}\end{array}$ & $\begin{array}{l}0.35 \\
0.71 \\
0.89 \\
0.97\end{array}$ & $\begin{array}{l}0.07 \\
0.78 \\
1.82 \\
2.88\end{array}$ & $\begin{array}{r}2.2 \\
-0.6 \\
-7.2 \\
-14.8\end{array}$ \\
\hline$a_{\text {CDOM }}(450)=0.03 \mathrm{~m}^{-1}, z_{\mathrm{CDON}}=20 \mathrm{~m}$ & 0.74 & 0.03 & 5.5 \\
\hline $\begin{array}{l}\operatorname{a}_{\mathrm{CDOM}}(450)=0.01 \mathrm{~m}^{-1}, z_{\mathrm{CDOM}}=10 \mathrm{~m} \\
a_{\mathrm{CDOM}}(450)=0.03 \mathrm{~m}^{-1}, z_{\mathrm{CDOM}}=10 \mathrm{~m} \\
a_{\mathrm{CDOM}}(450)=0.05 \mathrm{~m}^{-1}, z_{\mathrm{CDOM}}=10 \mathrm{~m} \\
a_{C D O M}(450)=0.07 \mathrm{~m}^{-1}, z_{\mathrm{CDOM}}=10 \mathrm{~m}\end{array}$ & $\begin{array}{l}0.78 \\
1.47 \\
1.57 \\
1.40\end{array}$ & $\begin{array}{l}0 \\
0 \\
0 \\
0\end{array}$ & $\begin{array}{r}6.0 \\
8.8 \\
10.1 \\
11.4\end{array}$ \\
\hline$a_{C D O M}(450)=0.03 \mathrm{~m}^{-1}, z_{C D O M}=1 \mathrm{~m}$ & 1.72 & 0 & 13.4 \\
\hline
\end{tabular}

When CDOM was distributed throughout the water column (the depth down to which CDOM is distributed within the water column will be referred to hereafter as $\left.z_{\mathrm{CDOM}}\right), \int_{z} \mathrm{GPP}_{\mathrm{ez}}$ always declined. In addition, if $z_{\text {CDOM }}$ is $<30 \mathrm{~m}$. the presence of CDOM can enhance I, GPP (Table 2). It follows then, that there exists a $z_{\text {CDOM }}$ at which $\mathrm{PP}{ }^{*}=0$, defined here as $z_{C \text { DOM }}{ }^{\circ}$. When $z_{\mathrm{CDOM}}>z_{\mathrm{C} \text { MOM }} \cdot{ }^{\circ}, \int_{\triangle} \mathrm{GPP}_{\mathrm{ez}}$ declines in the presence of CDOM Conversely, when $z_{C D O M}<$ $z_{\mathrm{CDOM}}{ }^{\circ}, \int_{?} \mathrm{GPP}_{\mathrm{C}}$ increases.

The value for $z_{\text {CDOM }}{ }^{\circ}$ is controlled in part by the absorption properties of the CDOM; if the CDOM is strongly absorbing, then $z_{C D O M}{ }^{*}$ must be shallower for CDOM to enhance $\int_{z} G_{P P}$. For example, when $a_{\mathrm{CDOM}}(450)=0.01 \mathrm{~m}^{-1}$ and $z_{\mathrm{CDOM}}$ was set in the model to $30 \mathrm{~m}$, then $\mathrm{PP}{ }^{*}=$ 2.2 (Table 2), indicating that the presence of CDOM enhanced $\int_{Z} \mathrm{GPP}_{\mathrm{e} L}$ and that $z_{\mathrm{CDOM}}{ }^{*}$ was $>30 \mathrm{~m}$. (If $z_{C D O M}{ }^{*}$ were equal to $30 \mathrm{~m}$, then $\mathrm{PP} \cdot$ would have been 0 ; if $z_{\mathrm{CDOM}}{ }^{\circ}$ were $<30 \mathrm{~m}$, then $\mathrm{PP}$ - would have been negative.) When acdom $(450)$ was increased to $0.03 \mathrm{~m}^{-1}$, then $\mathrm{PP}^{\cdot}=-0.6$, demonstrating that $z_{\mathrm{CDOM}}{ }^{\cdot}$ was $<30$ $m$. Within the range of values typically observed for $a_{C D O M}(450)$ in open waters, $z_{\text {CDOM }}{ }^{\circ}$ is greater than $10 \mathrm{~m}$. This can be seen increase $\mathrm{PP}^{+}$and an $89 \%$ increase in $\mathrm{PP}^{-}$. Consequently, $\mathrm{PP} \cdot$ dropped from -14.8 to -30.6 , indicating that the additional absorption by CDOM further suppressed rates of $\int_{z} \mathrm{GPP}_{\mathrm{ez}}$. Furthermore, for all simulations where CDOM was distributed uniformly with depth, PP ${ }^{*}$ was negative. This finding suggests that the decrease in $\int_{7} \mathrm{GPP}_{\mathrm{ez}}$ observed in the presence of CDOM in the standard run is applicable over a wide range of CDOM concentrations.

The magnitude of $\mathrm{PP}^{*}$ was also a function of the vertical distribution of CDOM. As CDOM (with fixed absorption properties, i.e. $a_{\mathrm{CnOM}}(450)=0.03 \mathrm{~m}^{-1}$ and $\mathrm{S}=$ $0.015 \mathrm{~nm}^{-1}$ ) was increasingly restricted to the shallower waters, $\mathrm{PP}^{+}$increased while $\mathrm{PP}^{-}$rapidly dropped to zero (Table 2). For example, when CDOM was restricted to the upper $30 \mathrm{~m}, \mathrm{PP}^{+}$increased slightly (relative to when CDOM was distributed over the euphotic depth) from 0.70 to $0.71 \mathrm{mg} \mathrm{C} \mathrm{m}^{-2} \mathrm{~h}^{-1}$ while $\mathrm{PP}^{-}$fell from 2.6 to $0.78 \mathrm{mg} \mathrm{C} \mathrm{m}^{-2} \mathrm{~h}^{-1}$; accordingly, $\mathrm{PP}$. rose from -14.8 to -0.6 . When CDOM was distributed only within the upper $20 \mathrm{~m}$ of the water column, PP+ had increased to $0.74 \mathrm{mg} \mathrm{C} \mathrm{m}{ }^{-3} \mathrm{~h}^{-1}, \mathrm{PP}^{-}$had fallen to $0.03 \mathrm{mg} \mathrm{C} \mathrm{m}^{-2} \mathrm{~h}^{-1}$, and $\mathrm{PP}^{-}$increased to 5.5. $\mathrm{PP}^{+}$ reached its peak of $1.72 \mathrm{mg} \mathrm{C} \mathrm{m}{ }^{-2} \mathrm{~h}^{-1}$ when CDOM was restricted to the topmost $1 \mathrm{~m}$ of the water column. These results indicate that when CDOM is restricted to within 20 to $30 \mathrm{~m}$ of the surface, its presence will enhance $\int_{z} \mathrm{GPP}_{\mathrm{ez}}$. for the case where $z_{C D O M}$ was set to $10 \mathrm{~m}$ (Table 2 ) and $\mathrm{PP} \cdot$ was always positive.

Increasing $S$, the slope of CDOM absorption spectra, increased PP. For example, raising $S$ from 0.012 to $0.030 \mathrm{~nm}^{-1}$ resulted in a rise in $\mathrm{PP}^{*}$ from -17.2 to -5.0 (Table 3). The increase in $S$ caused a reduction in $a_{C D O M}(\lambda)$ (see Eq. 2) at wavelengths longer than $450 \mathrm{~nm}$ and an increase in $a_{\mathrm{CDOM}}(\lambda)$ at shorter wavelengths. Consequently, the change in $\mathrm{PP}^{\cdot}$ was due both to an increase in $\mathrm{PP}^{+}$resulting from the additional absorption of UVR by CDOM in surface waters and to a decrease in $\mathrm{PP}^{-}$due to the reduction in the absorption of PUR at depth. The depth-dependent change in production resulting from changes in $S$ was small, however.

Table 3. Sensitivity of model to the spectral slope, $S$, from Eq. (2). $\mathrm{PP}^{+}\left(\mathrm{mg} \mathrm{C} \mathrm{m} \mathrm{m}^{-2} \mathrm{~h}^{-1}\right), \mathrm{PP}^{-}\left(\mathrm{mg} \mathrm{C} \mathrm{m}^{-2} \mathrm{~h}^{-1}\right)$, and PP $(\%)$ are defined in Table 2 . Unless otherwise noted, variable va!ues for all simulations were: day of year $=350$, latitude $=45^{\circ} \mathrm{S}$, $\left.z_{\mathrm{CDOM}}=100 \mathrm{~m},\left[\mathrm{O}_{3}\right]=344 \mathrm{DU},[\mathrm{ch}] \mathrm{a}\right]=0.1 \mathrm{mg} \mathrm{m}^{-3}, \mathrm{a}_{\mathrm{CDOM}}(450)$ $=0.03 \mathrm{~m}^{-1}$, and $\mathrm{C}: \mathrm{chl} 2=50(\mathrm{~g}: \mathrm{g})$

\begin{tabular}{|lllr|}
\hline Parameter & $\mathrm{PP}^{+}$ & $\mathrm{PP}^{-}$ & $\mathrm{PP}^{\cdot}$ \\
\hline$S=0.012 \mathrm{~nm}^{-1}$ & 0.59 & 2.80 & -17.2 \\
$S=0.018 \mathrm{~nm}^{-1}$ & 0.82 & 2.43 & -12.5 \\
$S=0.024 \mathrm{~nm}^{-1}$ & 1.05 & 2.13 & -8.4 \\
$S=0.030 \mathrm{~nm}^{-1}$ & 1.25 & 1.89 & -5.0 \\
\hline
\end{tabular}


Table 4. Sensitivity of model to chlorophyll a. $\mathrm{PP}^{+}\left(\mathrm{mg} \mathrm{C} \mathrm{m} \mathrm{Cm}^{-2}\right.$ $\left.\mathrm{h}^{-1}\right)$. PP $\left(\mathrm{mg} \mathrm{C} \mathrm{m}^{-2} \mathrm{~h}^{-1}\right)$, and PP. $(\%)$ are defined in Table 2. Unless otherwise noted, variable values for all simulations were: day of year $=350$, latitude $=45^{\circ} \mathrm{S}, z_{\mathrm{CDOM}}=100 \mathrm{~m},\left[\mathrm{O}_{3}\right]=$ $344 \mathrm{DU},[\mathrm{chl}$ a $]=0.1 \mathrm{mg} \mathrm{m}^{-3}, S=0.015 \mathrm{~nm}^{-1}, a_{\text {cDom }}(450)=$ $0.03 \mathrm{~m}^{-1}$, and $\mathrm{C}: \mathrm{chl} \mathrm{a}=50(\mathrm{~g}: \mathrm{g})$

\begin{tabular}{|lrrr|}
\hline Parameter & $\mathrm{PP}^{+}$ & \multicolumn{1}{c|}{$\mathrm{PP}^{-}$} & \multicolumn{1}{c|}{$\mathrm{PP}$} \\
\hline $\mid \mathrm{chl}$ a $]=0.1 \mathrm{mg} \mathrm{m}^{-3}$ (standard run) & 0.70 & 2.60 & -14.8 \\
$|\mathrm{chl} a|=0.5 \mathrm{mg} \mathrm{m}^{-3}$ & 3.19 & 11.57 & -14.4 \\
$|\mathrm{chl} a|=1.0 \mathrm{mg} \mathrm{m}^{-3}$ & 5.64 & 19.05 & -13.1 \\
$|\mathrm{chl} a|=5.0 \mathrm{mg} \mathrm{m}^{-3}$ & 14.39 & 23.04 & -3.5 \\
$|\mathrm{chl} a|=10.0 \mathrm{mg} \mathrm{m}^{-3}$ & 16.03 & 15.70 & 0.1 \\
\hline
\end{tabular}

Similarly, increasing concentrations of chl a throughout the water column will increase PP. As chl a increased from 0.1 to $5 \mathrm{mg} \mathrm{m}^{-3}$ in the standard run, $\mathrm{PP}$ increased from -14.8 to -3.5 (Table 4 ), indicating that the presence of CDOM will reduce depth-integrated primary production within a wide range of chl a concentrations. Only at concentrations of chl a greater than $-7 \mathrm{mg} \mathrm{m}^{-3}$ did the addition of CDOM result in a net increase in depth-integrated primary production $\left(\mathrm{PP}^{*}>0\right)$ (Table 4). At high chl a concentrations, i.e. $10 \mathrm{mg} \mathrm{m}^{-3}$, the addition of CDOM with an $a_{\text {CDOM }}(\lambda)>$ $0.015 \mathrm{~m}^{-1}$ will drive PP' positive.

The wavelength-dependent biological efficiency for damage to photosynthesis by $U V, \varepsilon(\lambda)\left[\left(\mu \operatorname{Ein} \mathrm{m}^{-2} \mathrm{~s}^{-1}\right)^{-1}\right.$. Cullen et al. 1992] and the flux of UV radiation were used by the model to calculate UV inhibition of primary production. Because relatively few measurements of $\varepsilon(\lambda)$ have been made, it was important to determine the sensitivity of the model to changes in $\varepsilon(\lambda)$. Simulations showed that even when $\varepsilon(\lambda)$ was increased 10 -fold, PP ' was only reduced by $\sim 65 \%$ and remained negative $(-5.4)$ (Table 5 ). This indicates that if phytoplankton are as much as 10 times more sensi-

Table 5 . Sensitivity of model to $\varepsilon(\lambda)$, the biological weighting function for the inhibition of phytoplankton photosynthesis by UV radiation (Cullen et al. 1992). $\mathrm{PP}^{+}\left(\mathrm{mg} \mathrm{C} \mathrm{m}^{-2} \mathrm{~h}^{-1}\right), \mathrm{PP}^{-}$(mg $\left.\mathrm{C} \mathrm{m}^{-2} \mathrm{~h}^{-1}\right)$, and $\mathrm{PP} \cdot(\%)$ are defined in Table 2 . Unless otherwise noted, variable values for all simulations were: day of year $=350$, latitude $=45^{\circ} \mathrm{S}, z_{\mathrm{CDOM}}=100 \mathrm{~m},\left[\mathrm{O}_{3}\right\rfloor=344 \mathrm{DU}$, $[\mathrm{chl} a]=0.1 \mathrm{mg} \mathrm{m}^{-3}, S=0.015 \mathrm{~nm}^{-1}, a_{C D O M}(450)=0.03 \mathrm{~m}^{-1}$, and $\mathrm{C}: \operatorname{chl} a=50(\mathrm{~g}: \mathrm{g})$

\begin{tabular}{|c|c|c|c|}
\hline Parameter & $\mathrm{PP}^{+}$ & $\mathrm{PP}^{-}$ & $\mathrm{PP}^{\cdot}$ \\
\hline Standard run & 0.70 & 2.60 & -14.8 \\
\hline$\varepsilon(\lambda)\left[\left(\mathrm{mW} \mathrm{m}^{-2}\right)^{-1}\right\rfloor$ & 103 & 258 & -127 \\
\hline$\varepsilon(\lambda)\left[\left(\mathrm{mW} \mathrm{m}^{-2}\right)^{-1}\right]$ & 1.03 & 2.58 & -12.1 \\
\hline $\begin{array}{l}\text { was increased by a factor of } 4 \\
\varepsilon(\lambda)\left\{\left(\mathrm{mW} \mathrm{m}^{-2}\right)^{-1}\right\}\end{array}$ & 1.38 & 2.52 & -10.0 \\
\hline was increased by a factor of 10 & 1.89 & 2.43 & -5.4 \\
\hline
\end{tabular}

tive to the presence of UVR than currently available photophysiological data suggest ( $\varepsilon$ is high), the addition of CDOM will still reduce depth-integrated primary production.

\section{DISCUSSION}

The relationship between the presence of CDOM and $\int_{\gamma} \mathrm{GPP}_{\mathrm{e}}$ is a complex one, depending upon the absorption properties and vertical distribution of CDOM (Table 6). A few generalizations are possible, however, based upon model results. Because UVR is most abundant within a few tens of meters of the sea surface, it is at these depths that light absorption by CDOM has the greatest net positive influence on rates of primary production, acting as a UV photoprotectant. In deeper waters, where little UVR remains, the presence of CDOM can only reduce rates of production via the absorption of PUR necessary for carbon fixation. Therefore, the balance between absorption of UVR and PUR by CDOM will determine whether the presence of CDOM enhances or inhibits $\int_{2} \mathrm{GPP}_{\mathrm{ez}}$.

When both CDOM and phytoplankton are distributed uniformly within the euphotic zone, the presence of CDOM always reduces $\int_{z} G P P_{e \%}$, regardless of the value of $a_{\text {CDom }}(450)$. The only exception appears to be when chl a concentrations exceed $-7 \mathrm{mg} \mathrm{m}^{-3}$ (Table 4 ), a condition rarely observed in the open ocean. In waters with more typical concentrations of chl a, the amount of UV photoprotection provided to phytoplankton by CDOM in surface waters is not as great as the reduction in the depth integrated rate of primary production due to the absorption of PUR. This pattern was found to be independent of either the magnitude and spectral shape of $a_{\text {coos }}(\lambda)$ or the sensitivity of the phytoplankton to UVR. For example, when $\varepsilon(\lambda)$ was increased 2- to 10 -fold (phytoplankton were rendered highly sensitive to UVR), the presence of CDOM still reduced $\int_{z} G_{P P}$, suggesting that the predicted decrease in $\int_{z} \mathrm{GPP}_{\mathrm{ez}}$ was not merely the result of an unrealistically low biological weighting function.

Table 6 . The effects of $z_{C D O M}$ and $a_{\mathrm{CDOM}}(450)$ on integrated gross primary productivity $\left(\int_{2} G P P_{e z}\right)$. The following generalizations apply only when $[\mathrm{chl} a]<7 \mathrm{mg} \mathrm{m}^{-3}$ and $S=0.015 \mathrm{~nm}^{-1}$

\begin{tabular}{|c|c|c|}
\hline$z_{C D O M}(m)$ & $a_{C D O M}(450)\left(\mathrm{m}^{-1}\right)$ & $\int_{z} G_{P P}$ \\
\hline$z_{C D O M}>30$ & $<0.07$ & \multirow{3}{*}{$\begin{array}{l}\text { Reduced } \\
\text { Enhanced }\end{array}$} \\
\hline $10<z_{\mathrm{CDOM}} \leq 30$ & $\begin{array}{l}>0.015 \\
<0.015\end{array}$ & \\
\hline$z_{\mathrm{CDOM}} \leq 10$ & $<0.07$ & \\
\hline
\end{tabular}


Unfortunately, relatively little field data are available describing the vertical distribution of CDOM within the water column. Our results suggest that regions characterized by deep mixed layers and approximately uniform chl a profiles, such as the North Atlantic or the open Southern Ocean, should experience a decline in $\int_{z} \mathrm{GPP}_{\mathrm{e} z}$ when $\mathrm{CDOM}$ is present. The Southern Ocean is of particular interest in this regard because of its exposure to high fluxes of UVB during periods of reduced stratospheric ozone concentration. Numerous field studies have shown that phytoplankton in surface waters experience reduced rates of photosynthesis when exposed to naturally occurring levels UVB (Karentz et al. 1991, Helbling et al. 1992, Smith et al. 1992, Holm-Hansen et al. 1993a, b, Cullen \& Neale 1994). Unfortunately, the influence of CDOM was never investigated during these studies to determine whether its presence was influencing the measured rates of UVR photoinhibition. Our model predicted that while under conditions of increased UVB flux (i.e. when ozone concentrations were reduced by $50 \%$ ) photoinhibition in near-surface waters was reduced when CDOM was present, but $\int_{2} \mathrm{GPP}_{\mathrm{ez}}$ continued to decline, even at high latitudes. In short, the presence of CDOM in the open Southern Ocean would probably diminish, but not eliminate, decreases in $\int_{z} G_{\mathrm{e} z}$ associated with increased UVB fluxes beneath the ozone hole.

The presence of CDOM should enhance $\int_{z} \mathrm{GPP}_{\mathrm{ez}}$ in areas of equatorial upwelling, marginal ice edge zones, frontal zones, and eddies. These are locations where $a_{\text {CDOM }}(450)$ is likely to be small (less than $\sim 0.015 \mathrm{~m}^{-1}$ ) or $z_{\mathrm{CDOM}}$ shallow (less than $\sim 40 \mathrm{~m}$ ) (Table 2) or where phytoplankton are restricted to near-surface waters. $\int_{z} \mathrm{GPP}_{\mathrm{ez}}$ will be enhanced under these conditions because even CDOM with a relatively low absorption coefficient will absorb a substantial fraction of UVR at the sea surface relative to its absorption of PUR. These conditions favor enhanced phytoplankton growth. As CDOM absorption increases, however, the benefits of UVR absorption will diminish because proportionally less UVR will be left to be absorbed at a given depth and the availability of PUR will be reduced, causing a reduction rather than an increase in $\int_{2} \mathrm{GPP}_{\mathrm{e} z}$. Similarly, when $z_{\mathrm{CDOM}}$ increases, little UVR will be transmitted to depth (it is effectively absorbed in surface waters by CDOM and seawater), and the presence of CDOM will reduce PUR in deeper waters and $\int_{z} G_{P P}$ will decline.

The beneficial effect of CDOM absorption on $\int_{z} G P P_{\mathrm{ez}}$ will be exaggerated when the spectral slope, $S$, is large because the ratio of absorbed UVR:PUR will increase. This may be an important consideration in the open ocean where values for $S$ tend to be higher $(0.015$ to $0.029 \mathrm{~nm}^{-1}$ ) than those measured from CDOM col- lected in coastal regions (Bricaud et al, 1981, Green \& Blough 1994). Therefore, the presence of CDOM is most advantageous to depth-integrated phytoplankton production when $a_{\mathrm{CDOM}}(450)$ is small, $S$ is large, and $z_{\text {CDOM }}<30 \mathrm{~m}$.

When CDOM is highly absorbing, the effect of CDOM on $\int_{z} G P P_{e z}$ depends upon $a_{C D O M}(450), z_{C D O M}$ and the depth over which phytoplankton are distributed $\left(z_{\mathrm{chl}}{ }_{\mathrm{a}}\right)$. This is the most difficult case to generalize. Clearly, however, as $a_{\mathrm{CDOM}}(450)$ increases, $z_{\mathrm{CDOM}}$ or $z_{\mathrm{Chl}}$ a must decrease accordingly (to $-30 \mathrm{~m}$ ) in order for the presence of CDOM to enhance $\int_{z} \mathrm{GPP}_{\mathrm{ez}}$. CDOM and phytoplankton are often restricted to the surface layer in waters that are markedly stratified and exhibit a high degree of biological activity, such as in coastal regions during the spring and at river mouths. CDOM concentrations $>2 \mathrm{~g}$ CDOM-C $\mathrm{m}^{-3}$ have been reported in coastal regions such as the Delaware Bight, USA, (DeGrandpre et al. unpubl.) and in the Orinoco River, Venezuela, outflow plume ( 3.1 g CDOM-C $\mathrm{m}^{-3}$; Blough et al. 1993). At concentrations of this magnitude, even weakly absorbing CDOM would tend to remove a great deal of the PUR available to phytoplankton and cause a reduction in $\int_{z} \mathrm{GPP}_{\mathrm{ez}}$. However, because terrigeneous sources of CDOM generally have a high specific absorption coefficient $\left[a^{\circ}{ }_{\mathrm{CDOM}}(450)=\right.$ 0.51 to $1.76 \mathrm{~m}^{2} \mathrm{~g}$ CDOM-C m${ }^{-3}$; Zepp \& Schlotzhauer 1981, Blough et al. 1993, and Blough \& Green 1995], phytoplankton associated with river outflow plumes would experience reduced depth integrated rates of production unless either $z_{\mathrm{CDOM}}$ or $z_{\mathrm{chl}}$ a was very small (<10 m).

Reducing $\left[\mathrm{O}_{3}\right]$ in the model had little influence on the magnitude of the change in $\int_{z} G \mathrm{GP}_{\mathrm{ez}}$ resulting from light absorption by CDOM. This insensitivity to $\left[\mathrm{O}_{3}\right]$ was predicted regardless of $a_{\text {CDOM }}(450)$ and whether CDOM was distributed uniformly throughout the euphotic zone or restricted to surface waters. This was somewhat surprising considering that the flux of UVB at the sea surface is much greater when $\left[\mathrm{O}_{3}\right]$ is low. In fact, under conditions of reduced ozone the increased flux of UVB at the sea surface reduced $\mathrm{PP}^{+}$slightly. At depth, $\mathrm{PP}^{-}$remained relatively unchanged. Consequently, while PP* tended to decrease when $\left[\mathrm{O}_{3}\right]$ decreased, it did so only slightly. Therefore, even in waters where the flux of UVB is relatively high, such as the Southern Ocean when the ozone hole is present, CDOM is expected to provide little or no added benefit to phytoplankton production.

The effect of differences in phytoplankton community structure on $\int_{z} G_{P P}$ was not considered but may have important implications when applying model results to field conditions. For example, Karentz et al. (1991) have shown that interspecific differences in UVB sensitivity among Antarctic diatoms can vary by a 
factor of $\leq 50$. However, the value for $\varepsilon(\lambda)$ determined for a single species, Phaeodactylum sp., was used in the model to estimate UV inhibition. If this diatom species proves to be particularly sensitive to UVB (relative to other species), then the presence of CDOM will be less beneficial than predicted by the model, even in surface waters where the flux of UVB is greatest. The use of incorrect values for $\varepsilon(\lambda)$ is not likely to change our general conclusions, however, because the model was not particularly sensitive to $\varepsilon(\lambda)$ (Table 5 ).

Although the optical properties of CDOM have received a great deal of attention in recent years, little is currently known about vertical distributions of CDOM in the water column and how absorption properties vary with depth or with season. Even less is known about the dynamics of CDOM degradation and formation in the open ocean. Although remote sensing techniques have been used recently to measure CDOM absorption over wide areas of the ocean (Hoge et al. 1995a, b, Vodacek et al. 1995), much more must be learned about the distribution of CDOM on a global scale before the results of the present study can be generalized to a wide range of field conditions. This is particularly true for regions of high biological activity where the precise effect of CDOM on $\int_{z} G_{\text {PPP }}$ is determined by $z_{\text {CDOM }}$ and $a_{\text {CDON }}(450)$, quantities which are virtually unknown for most waters, and by $z_{\mathrm{chl} \text { d }}$. Even in deeply mixed water columns where the presence of CDOM always reduces $\int_{2} G P P_{\text {ez }}$, the magnitude of this reduction cannot be estimated without knowledge of CDOM distributions and optical properties

Acknowledgements. We thank Neil Blough and Tony Vodacek for their help during preparation of this manuscript. This research was supported by NASA RTOP 438-20-10 to K.R.A. and through a National Research Council Postdoctoral Fellowstip to C.W.B.

\section{LITERATURE CITED}

Arrigo KR (1994) The impact of ozone depletion on phytoplankton growth in the Southern Ocean: large-scale spatual and temporal variability. Mar Ecol Prog Ser 114:1-12

Arrigo KR, Sullivan CW (1994) A high resolution bio-optical model of microalgal growth: tests using sea ice algal community time serıes data. Lumnol Oceanogr 39:609-631

Blough NV, Green SA (1995) Spectroscopic characterization and remote sensing of non-living organic matter. In: Zepp RG, Sonntag C (eds) The role of non-living organic matter in the earth's carbon cycle. John Wiley \& Sons Ltd, New York, p 23-45

Blough NV, Zafiriou OC. Bonilla J (1993) Optical absorption spectra of waters from the Orinoco River outflow: terrestrial input of colored organic matter to the Caribbean. $J$ Geophys Res 98:2271-2278

This article was presented by O. Holm-Hansen (Senior Editorial Advisor), La Jolla, Callfornia, USA
Bncaud A, Morel A, Prieur L (1981) Absorption by dissolved organic matter of the sea (yellow substance) in the UV and visible domains. Limnol Oceanogr 26:43=53

Carder KL, Steward RG, Harvey GR, Ortner PB (1989) Marine humic and fulvic acids: their effects on remote sensing of ocean chlorophyll. Limnol Oceanogr 34:68-81

Cullen JC, Neale PJ (1994) Ultraviolet radiation, ozone depletion, and marine photosynthesis. Photosynth Res 39: $303-320$

Cullen JC, Neale PJ, Lesser MP (1992) Biological weighting function for the inhibition of phytoplankton photosynthesis by ultraviolet radiation. Science 258:646-650

Green SA, Blough NV (1994) Optical absorption and fluorescence properties of chromophoric dissolved organic matter in natural waters. Limnol Oceanogr 39:1903-1916

Helbling EW, Villafane V. Ferrario M, Holm-Hansen O (1992) Impact of natural ultraviolet radiation on rates of photosynthesis and on specific marine phytoplankton species. Mar Ecol Prog Ser 80:89-100

Hoge FE, Vodacek T, Blough NV (1993) Inherent optical properties of the ocean: retrieval of the absorption coefficient of chromophoric dissolved organic matter from fluorescence measurements. Limnol Oceanogr 38:1394-1402

Hoge FE, Vodacek A, Swift RN, Yungel JK, Blough NV (1995) Inherent optical properties of the ocean: retrieval of the absorption coefficient of chromophoric dissolved organic matter from airborne laser fluorescence measurements. Appl Optic 34:7032-7038

Hoge FE, Williams MK, Swift RN, Yungel JK, Vodacek A (1995) Progress toward global oceanic carbon assessment: satellite retrieval of the absorption coefficient of chromophoric dissolved organic matter in continental margins. J Geophys Res 100:24847-24854

Holm-Hansen O, Helbling EW, Lubin D (1993a) Ultraviolet radiation in Antarctica: inhibition of primary production Photochem Photobiol 58:567-570

Holm-Hansen O, Lubin D. Helbling EW (1993b) Ultraviolet radiation and its effects on organisms in aquatic environments. In. Young A (ed) Environmental UV photobiology. Plenum Press, New York, p 379-425

Karentz D, Cleaver JE, Mitchell DL (1991) Cell survival characteristics and molecular responses of Antarctic phytoplankton to ultraviolet-B radiation. J Phycol 27:326-341

Kopelevich OV, Rodionov VV, Stupakova TP (1987) Effect of bacteria on optical characteristics of ocean water. Oceanology $27: 696-700$

Mitchell BG, Vernet M. Holm-Hansen O (1989) Ultraviolet light attenuation in Antarctic waters in relation to particulate absorption and photosynthesis. Antarct J US 25: $179-181$

Smith RC, Prezelin BB, Baker KS, Bidigare RR, Boucher NP, Cooley T, Karentz D, Macintyre S, Matlick HA, Menzies D. Ondrusek M. Wan Z, Waters KJ (1992) Ozone depletion: ultraviolet radiation and phytoplankton brology in Antarctic waters. Science 255:952-959

Vodacek A, Hoge FE, Swift RN, Yungel RN, Blough NV (1995) The use of $i n$ situ and airborne fluorescence measurements to determine UV absorption coefficients and DOC concentrations in surface waters. Limnol Oceanogr 40:411-415

Zepp RG, Schlotzhauer PF (1981) Comparison of the photochemical behavior of various humic substances in water. IIT. Spectroscopic properties of humic substances. Chemosphere 10:479-486

Manuscript first received: September 26, 1995

Revised version accepted: April 4, 1996 